\title{
The Role of Financial Literacy in Financial Management Ability to Prepare The Retirement Independently
}

\author{
Ade Gunawan', Radiman², Delyana Rahmawany Pulungan ${ }^{3}$ and Murviana Koto ${ }^{4}$ \\ \{adegunawan@umsu.ac.id ${ }^{1}$ \} \\ 1,2,3,4 Management Study Program, Faculty of Economics and Business, University of Muhammadiyah \\ Sumatera Utara, Medan, Indonesia
}

\begin{abstract}
This study aims to determine (1) the level of financial literacy and the ability to manage the lecturers' finance at the Faculty of Economics and Business UMSU (2) to determine the effect of financial literacy and the ability to manage the lecturers at the UMSU Faculty of Economics and Business on retirement preparation. This research is quantitative descriptive, and this type of research is explanatory research. The study population was 94 permanent lecturers who taught at the Faculty of Economics and Business UMSU. The sample of this study was a saturated sample which was all members of the population into the study sample. The data analysis technique was used Structural Equation Modelling (SEM) analysis with the help of AMOS software. The results showed (1) the level of financial literacy of lecturers was still very low (low level), the majority of which was dominated by female lecturers (2) financial literacy influences financial behaviour with a positive relationship direction (3) financial literacy influences retirement preparation with the direction of the negative relationship (4) the ability to manage finances influences retirement preparation with the direction of a positive relationship (5) financial literacy influences retirement preparation through the ability to manage finances.
\end{abstract}

Keywords: Financial literacy, financial management, financial management, retirement

\section{Introduction}

development of communication and information technology that makes people into communities with consumptive behaviour makes people forget to prepare themselves for their future. The public forgets that the period for enjoying retirement costs a lot because it is no longer productive in the age phase to generate income for daily living needs.

The Financial Services Authority (FSA) (2016) has data that the percentage of workers with a new retirement program reaches 13.5 million workers or around 27 percent of the 50 million formal workers in Indonesia. Badan Pusat Statistik Indonesia (BPS) (2016) also said that the number of informal workers was 68.2 million, most of whom also did not have a pension guarantee (Otoritas Jasa Keuangan, 2016) The number of informal workers was 68.2 million, most of whom also did not have a pension guarantee (BPS, 2016) That is, awareness of preparing to face retirement is still very low, both in terms of employees and employers. OJK survey results related to financial literacy and financial inclusion, obtained data that the percentage of workers who have a new pension program reaches only 13.5 million workers or about 27 percent of the 50 million formal workers in this republic(Otoritas Jasa Keuangan, 2016). Nearly $96 \%$ of respondents will have the same or almost the same lifestyle in retirement. But in fact there are 24 percent of respondents only set aside 10 percent of their savings as pension funds and $90 \%$ of workers are not ready to face retirement because they do not have good financial preparation. Working people must rely on retirement from funds or 
pension programs provided by companies or institutions where they work so that there is an assumption that independent pension preparations such as buying productive assets or making investments by buying assets such as property or mutual funds are no longer important. Even though the investment is a cash flow when in retirement.

One of the efforts made by someone to prepare for retirement is to save, but generally the savings held still tend to be used to fulfill consumer needs and goods that are useful for the short term.( bisnis.news.viva.co.id,2011). Preparation for retirement funding is a need with long-term benefits. This is due to the condition at the time of retirement a person only has a small amount of income compared to when they were still in the productive age. Indonesian society is still dominated by groups that do not have the preparation of retirement funds because of their hopes that the pension costs will be borne by their children(Liman and Hananto, 2009).

Financial difficulties become one of the threats to human life, not only at present or at retirement age. Difficulties in managing finances are an illustration of the low level of financial literacy that illustrates how behavior in managing finances or financial capability. The way a person spends money depends on the level of their financial literacy ( finansialku.com, 2017). Lusardi and Mitchell, (2011) mentions in his research that people who have a high level of financial literacy would prefer to plan for their retirement because they expect a comfortable and affluent old age. So they will look for financial literacy improvement programs to improve their knowledge and financial capabilities for the better.

Everyone will definitely enter retirement including the lecturers at the Faculty of Economics, University of Muhammadiyah Sumatera Utara (UMSU). Preparations to enter retirement must be the main focus, especially in finance, because entering retirement there will be a decline in income. Even though the necessities of life do not experience a decline, even the cost of fulfillment will be even higher with a comparison of the value of money which will also be far changed. The lecturers at the Faculty of Economics and Business at the University of Muhammadiyah Sumatera Utara (UMSU) are expected not only to depend on the funds or pension programs provided but must be able to find other sources of funds that can be managed into productive funds that will be in preparation for retirement. But the challenge is whether all lecturers have good financial literacy, which has an impact on the ability to manage finances well, especially in preparing for retirement without having to rely on funds or pension programs provided by universities and government. Therefore, based on the above explanation, the authors are interested in digging deeper into the level of financial literacy of the lecturers of the Faculty of Economics and Business at University of Muhammadiyah Sumatera Utara (UMSU) and how it relates to the ability to manage finances in preparation for retirement in the future.

\section{Theory}

\subsection{Financial Literacy}

Financial literacy is knowledge in managing finances related to general knowledge about financial management, savings and loans, insurance, and investment(Chen and Volpe, 1998). The higher the level of one's financial literacy will be reflected in their financial behaviour and policies in managing finances(Huston, 2010).

Financial literacy is the ability to read, analyse, manage and communicate about personal financial conditions related to material welfare. Including the ability to distinguish financial choices, the ability to discuss financial problems, can make future financial planning well and the ability to competently respond to any uncertainties that can occur and affect every day 
financial decisions, including things that are common in the economy(Cude et al., 2006; Huston, 2010).

\subsection{Financial Capability}

Someone who has financial capability has a financial plan for their future, finds and uses the information they need and knows when to ask advice from competent parties, then can understand and act on the advice given, thus leading to greater participation in the market financial services.

One can be said to have a good financial capability if it has been able to make the right financial decisions, is able to calculate and be able to manage finances effectively, understand how to manage credit and debt and be able to assess the need for insurance and protection. Financial capability is measured in terms of how well people meet needs, make financial planning ahead, choose and manage financial products, and have the skills and knowledge in making financial decisions(Lusardi, 2011).

\subsection{Retirement Preparation}

One of the keys to success in entering a good retirement is preparation. Someone who already has preparation for his retirement needs will be more successful in adapting to his life changes (Cavanaugh, 2006). (Ricciardi and Simon, H, (2000) stated that one of the inventories that must be prepared in measuring retirement readiness as a form of activity is a useful task, especially making money or choosing forms of activity which are active investments or determining the use of pension assistance provided by companies or government.

Pension planning in the financial context can be defined as the allocation of savings that will be used during retirement with the aim of achieving financial independence (wikipedia, 2017b). Lusardi and Mitchell, $(2007,2011)$ in his research found that there was a positive relationship between financial literacy and specific retirement planning measures, related to the calculation of savings needs for retirement.

\subsection{Research Purposes}

To identify the level of financial literacy and the ability to manage finances of lecturers at the Faculty of Economics and Business at University of Muhammadiyah Sumatera Utara (UMSU) regarding the preparation of retirement.

To find out how the skill level of the lecturers at the Faculty of Economics and Business at the University of Muhammadiyah Sumatera Utara (UMSU) in managing their personal finances related to preparation for retirement in the future.

To find out how the role of financial literacy and the ability to manage finances of lecturers at the Faculty of Economics and Business at University of Muhammadiyah Sumatera Utara (UMSU) to prepare for retirement.

\subsection{Hypothesis}

Lecturer at the Faculty of Economics and Business UMSU has a high level of financial literacy.

Financial literacy influences the financial management capabilities of lecturers at Faculty of Economics and Business UMSU. Financial literacy influences the retirement preparation of lecturers at Faculty of Economics and Business UMSU. The ability to manage finances 
influences the retirement preparation of the lecturers at Faculty of Economics and Business UMSU. Financial literacy influences the retirement preparation of lecturers at Faculty of Economics and Business UMSU through the ability to manage finances.

\section{Method Of Research}

This research is descriptive quantitative and explanatory type of research. The population is 94 permanent lecturers at the Faculty of Economics and Business UMSU. The sample of this study is saturated sample, that is, all members of the population are made as research respondents. The sampling technique is random sampling.

The analysis technique uses structural equation modelling (SEM) analysis with the help of AMOS software. Data collection techniques using the methods of (1) interview (2) documentation and (3) questionnaires.

\section{Data Analysis And Discussion}

\subsection{Descriptive Statistics}

The survey results show that the lecturers of Faculty of Economics and Business UMSU have a low level of financial literacy. The majority of female lecturers (37\%) while male lecturers $(34 \%)$ who have a low level of financial literacy. Groups with middle and high financial literacy levels both have equal portions of men and women, each of which is $4 \%$.

Then it is also known that lecturers with the age range of 25-35 years are also a group of lecturers who have a low level of financial literacy. For groups of respondents with an average income category each month there are $40 \%$ who have income between IDR $1,000,000$, - up to IDR 5,000,000, have a low level of financial literacy while the rest are spread in categories of groups that have a high level of financial literacy is a group of respondents with an average income per month above IDR 20,000,000. For the category of respondents with an average monthly income of IDR 5,000,000, - up to IDR $10,000,000$, have a low financial literacy rate of $19 \%$. and the middle level financial literacy level is $7 \%$. The rest is the respondent group with an average monthly income category of IDR10,000,000, - up to IDR15,000,000, - is a group with low financial literacy levels of $12 \%$ and $1 \%$ have a medium level of financial literacy.

The category on average expenditure per month is known to be the majority of respondents with a total expenditure of IDR1,000,000 - up to IDR5,000,000 - 49\% have a low level of financial literacy and $4 \%$ have a medium level of financial literacy. Then in the group of respondents with an average monthly expenditure of IDR 5,000,000 up to IDR 10,000,000 have a low level of financial literacy as much as $22 \%$ and the remaining $4 \%$ have a medium level of financial literacy. The next respondent group is a group that has an average monthly expenditure of IDR10,000,000, - up to IDR15,000,000, - all have a low level of financial literacy that is $3 \%$, and finally there are $4 \%$ of respondents who have low levels of financial literacy in the average monthly expenditure category of more than IDR 20,000,000.

\subsection{Results}

The following is a picture of Structural Analysis Equation Modelling (SEM) after modification: 


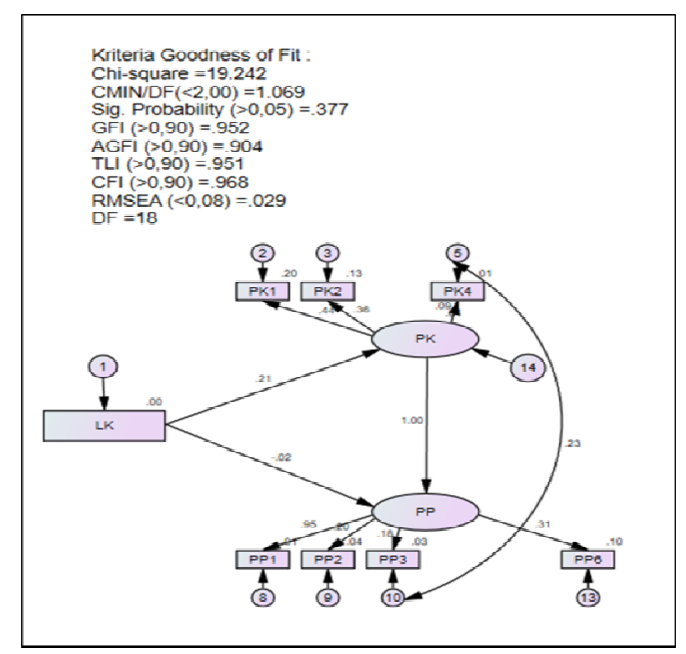

Fig.1. Full Research Model Test

Then the suitability of the model is tested with the following Goodness of Fit criteria:

Table 1. The Goodness of Fit Index Model

\begin{tabular}{|c|c|c|c|}
\hline $\begin{array}{l}\begin{array}{l}\text { Goodness } \\
\text { Index }\end{array} \\
\end{array}$ & Cut off Value & Results & $\begin{array}{l}\text { Model } \\
\text { Evaluation }\end{array}$ \\
\hline Chi-Square $(\mathrm{df}=18)$ & $\begin{array}{l}\text { Diharapkan } \\
\text { Kecil }\end{array}$ & 19,242 & Good Fit \\
\hline Probability & $>0,050$ & 0,377 & Good Fit \\
\hline GFI & $>0,90$ & 0,952 & Good Fit \\
\hline AGFI & $>0,90$ & 0,904 & Good Fit \\
\hline TLI & $>0,90$ & 0,951 & Good Fit \\
\hline CFI & $>0,90$ & 0,968 & Good Fit \\
\hline CMIN/DF & $<2,00$ & 1,069 & Good Fit \\
\hline RMSEA & $<0,084$ & 0,029 & Good Fit \\
\hline
\end{tabular}

Data in Table 1. shows the results of the feasibility test of goodness of fit after modification of the model shows that the overall evaluation model shows the results that have been in a range of good values (fit). This model has met the criteria for goodness of fit, so that this model is eligible and acceptable.

Test results with confirmatory analysis and previous SEM have shown that the model developed in this study can be accepted according to the fit model. Based on this fit model, it can be tested against the hypothesis. This study consists of five proposed hypotheses. The interpretation of the results of the analysis with the AMOS program can be seen in Table 2 . below:

Table 2 . Hypothesis Results

\begin{tabular}{lllll}
\hline & & Estimate $(\beta)$ & S.E. & C.R. \\
\hline $\begin{array}{l}\text { Financial } \\
\text { literacy }\end{array}$ & $\begin{array}{l}\text { Financial } \\
\text { behavior }\end{array}$ & 0,208 & 0,049 & 1,013 \\
\hline $\begin{array}{l}\text { Financial } \\
\text { literacy }\end{array}$ & $\begin{array}{l}\text { Retirement } \\
\text { preparation }\end{array}$ & $-0,024$ & 0,147 & 0,128 \\
\hline
\end{tabular}




\begin{tabular}{lllll}
\hline $\begin{array}{l}\text { Financial } \\
\text { behavior }\end{array}$ & $\begin{array}{l}\text { Retirement } \\
\text { preparation }\end{array}$ & 1,005 & 0,180 & 8,082 \\
\hline
\end{tabular}

The C.R value above shows the critical ratio value obtained from the estimated value divided by the standard error (S.E). The higher the C.R value, the more significant. If our sample size is large, then the C.R value above 1 will produce a significant estimated value at the level of $5 \%$, whereas if it is above 2 it will be significant at the level of $1 \%$. Based on the table above, the results of testing the hypothesis are as follows:

Hypothesis 1: Respondents' level of financial literacy. The results of the analysis show that the level of lecturers financial literacy of the Faculty of Economics and Business UMSU is still in a low level of literacy, which is included in the low level category (financial knowledge is below $60 \%$ ).

Hypothesis 2: Financial literacy has a positive effect on financial management behaviour. This can be seen from the path coefficient $(\beta)$ which has a positive sign of 0.208 . Every increase in financial literacy by 1 unit will only have an impact on improving financial management behaviour by 0.208 or $20.8 \%$.

Hypothesis 3: Financial literacy has a negative effect on retirement preparation. This can be seen from the path coefficient $(\beta)$ which has a negative sign of -0.024 . These results indicate that meaningful financial literacy negatively affects retirement preparation but is insignificant.

Hypothesis 4: The ability to manage finances has a positive effect on retirement preparation. This can be seen from the path coefficient $(\beta)$ which has a positive sign of 0.887 . These results indicate that the ability to manage finances affects Pension preparation as much as $88.7 \%$.

Hypothesis 5: Financial literacy influences pension preparation through the ability to manage finances amounting to 0.209 . This data means that this variable can be explained by $20.9 \%$ by the variables of financial behaviour as intervening. Every increase in financial literacy by 1 unit will have an impact on increasing pension preparation by 0.209 units or by $20.9 \%$.

The results of this study are supported by Lusardi, (2011) said that the majority of Americans do not make financial plans for their retirement or for the cost of educating their children in college. The study also found that the majority of Americans do not have emergency funds and good debt management skills, even though most of the population has debt. There are more than one in five Americans using alternative (and often expensive) loan methods other than banking institutions, such as salary loans at the place they work, tax refunds, pawnshops. And the most worrying is that many people were not informed and knowledgeable about their loan requirements before deciding to borrow, not knowing the mortgage requirements they had to meet or the interest rates they paid for their loans (Lusardi, 2011; Lusardi and Tufano, 2015)

Hui, Taylor Shek-wai, (2016) mentions that Improving financial knowledge and skills for seniors and adults who will enter retirement is needed. This study also looks at how knowledge and trust relate to three main things in financial behaviour for retirement preparation: money and debt management, money planning and savings for the future, and financial management practices are also the best protection measures. High financial literacy alone is not enough to build the desired financial behaviour. Financial literacy surveys in many developed countries show that a lack of knowledge about products and financial practices is still high. And this can hamper someone's desire to invest to prepare for a good retirement, so that it can damage their welfare in old age (Lusardi and Mitchell, 2007). 


\section{Conclusions}

This study concludes that the lecturers of the Faculty of Economics and Business UMSU have a low level of financial literacy which are dominated by female lecturers. Financial literacy and financial management skills are able to play a real and strong role to assist the preparation of the retirement period. The ability to manage finances is an intervening variable that mediates the relationship between financial literacy and retirement preparation, meaning that a good level of financial literacy will help the lecturers to manage their finances well in order to successfully prepare their retirement.

\section{Acknowledgements}

This research is fully funded by the University of Muhammadiyah Sumatera Utara. Researchers would like to thank to UMSU and LP2M for helping and providing support both morally and materially to the completion of this research. Researchers hope that later the results of this study will be input for lecturers to improve their financial literacy so that they are able to manage finances well for preparing of a safe and comfortable retirement.

\section{References}

[1] Badan Pusat Statistik. (2016) No Title. Available at: https://www.bps.go.id/. (Accessed: 15 October 2017).

[2] Cavanaugh, J. C. and F. B.-F. (2006) Adult Development and Aging. 5th edn. USA: Thomson Wadsworth.

[3] Chen, H. and Volpe, R. . (1998) 'An Analysis of Personal Financial Literacy Among College Student', Financial Services Review, 7(2), pp. 107-128.

[4] Cude, B. J. et al. (2006) 'College Students and Financial Literacy:What They Know and What We Need to Learn', Eastern Family Economics and Resource Management Association.

[5] Hui, Taylor Shek-wai, et al (2016) The Role Of Financial Literacy In Financial Decisions And Retirement Preparedness Among Seniors And Near-Seniors. Social Research and Demonstration Corporation.

[6] Huston, S. . (2010) 'Measuring financial literacy', Journal of Consumer Affairs, 44(2).

[7] Liman, N. and Hananto, L. . (2009) 'Financial Planning Determination of Retirement Fund For Indonesian People: The Significant of Expense Ratio', Journal of Applied Finance and Accounting, 247.

[8] Lusardi, A. (2011) American's Financial Capability. No. 17103. D14.

[9] Lusardi, A. and Mitchell, O. S. (2007) 'Financial Literacy And Retirement Preparedness: Evidence And Implications For Financial Education', Business Economic.

[10] Lusardi, A. and Mitchell, O. S. (2011) 'Financial Literacy And Retirement Planning In The United States', Journal of Pension Economics and Finance., 10(4), pp. 509-525.

[11] Lusardi, A. and Tufano, P. (2015) 'Debt literacy, financial experiences, and overindebtedness', Journal of Pension Economics and Finance, 14(4). doi: $10.1017 / \mathrm{S} 1474747215000232$.

[12] No Title (2011). Available at: http://bisnis.news.viva.co.id (Accessed: 15 October 2017).

[13] No Title (2017a). Available at: http://finansialku.com (Accessed: 15 October 2017).

[14] No Title (2017b). Available at: http://wikipedia.com (Accessed: 28 October 2017). 
[15] Otoritas Jasa Keuangan (2016) No Title. Available at: http://www.ojk.go.id/. (Accessed: 15 October 2017).

[16] Ricciardi, V. and Simon, H, K. (2000) 'What is Behavior in Finance?', Business, Education, and Technology Journal., pp. 1-9. 